\title{
Response of Rabbiteye Blueberry (Vaccinium ashei Reade) to the Growth Regulators CPPU and Gibberellic Acid
}

\author{
D. Scott NeSmith ${ }^{1}$ \\ Department of Horticulture, Georgia Station, Griffin, GA 30223-1797 \\ Additional index words. $N$-(2-chloro-4-pyridyl)- $N^{\prime}$-phenylurea, $\mathrm{GA}_{3}$, fruit set, berry size
}

Abstract. Experiments were conducted during 1999 and 2000 at Griffin, Ga., with rabbiteye blueberries (Vaccinium ashei Reade) to determine how the growth regulator CPPU affected fruit set, berry size, and yield. CPPU (applied at two different timings) was used alone, and in conjunction with $\mathrm{GA}_{3}$ on mature, field-grown 'Tifblue' plants. A control treatment without either growth regulator was also included. The CPPU concentration used was $10 \mathrm{mg} \cdot \mathrm{L}^{-1}$ (a single application per treatment), and the $\mathbf{G A}_{3}$ concentration used was $200 \mathrm{mg} \cdot \mathrm{L}^{-1}$ (two applications per treatment). Results from both years showed a positive benefit of CPPU with respect to fruit set and berry size, especially in the absence of $\mathrm{GA}_{3}$. Depending on timing, berry number per plant was increased by more than $200 \%$ in 1999 using CPPU. Berry size increases of more than $30 \%$ occurred in 2000 when CPPU alone was applied at $17 \mathrm{~d}$ after flowering (DAF). CPPU did not increase berry size of $\mathrm{GA}_{3}$-treated plants in either year. Total yield per plant during 2000 was 5.0,7.1, and $8.3 \mathrm{~kg}$ for control, CPPU applied 7 DAF, and CPPU applied 17 DAF treatments, respectively, without GA $\mathbf{A}_{3}$. While CPPU did substantially increase fruit set, berry size, and yield of 'Tifblue', there was a notable delay in fruit ripening. These results suggest that CPPU may be useful for increasing yield of rabbiteye blueberries under conditions of inadequate fruit set (such as occurs in much of the Southeast), but a delay in ripening will likely result. Chemical names used: $N$-(2-chloro-4-pyridyl)- $N^{\prime}$-phenylurea (CPPU); gibberellic acid $\left(\mathrm{GA}_{3}\right)$.

Rabbiteye blueberry production has been on the increase throughout the southeastern United States over the past few years (Moore, 1994; Scherm et al., 2002). Problems of poor fruit set of rabbiteye blueberries due to erratic or inadequate pollination, which can lead to substandard fruit yields, have been recognized for years (Lyrene and Crocker, 1983; Lyrene and Goldy, 1983). In a recent report (Scherm et al., 2002), over $65 \%$ of growers surveyed in Georgia declared poor fruit set as a major or moderate horticultural problem.

There has been considerable research efforts in Georgia over the past decade with the growth regulator gibberellic acid $\left(\mathrm{GA}_{3}\right)$ aimed at overcoming some of the fruit set problems with rabbiteye blueberry. NeSmith and Krewer (1992) disclosed that the degree of activity of $\mathrm{GA}_{3}$ depends on the stage of flower bud development at the time of application. It was further demonstrated that $\mathrm{GA}_{3}$ could be used to induce fruit set of freeze-damaged blueberries (NeSmith et al., 1995, 1999). Other information on response of rabbiteye blueberry to $\mathrm{GA}_{3}$ has also recently been reported (NeSmith and Krewer, 1997a, 1997b, 1999). GA 3 has become widely used by growers, particularly in

Received for publication 4 Oct. 2001. Accepted for publication 24 Feb. 2002. A contribution of the Univ. of Georgia Agricultural Experiment Stations, Georgia Station, Griffin. This research was supported, in part, by state and Hatch Act funds allocated to the Georgia Agricultural Experiment Stations. The author also gratefully acknowledges financial assistance from Valent Biosciences Corp. and MBG Marketing.

${ }^{1}$ Professor the southeastern United States, to increase fruit set and yield of rabbiteye. In fact, a recent survey indicated that more than $50 \%$ of the acreage in Georgia received applications of $\mathrm{GA}_{3}$ (Scherm et al., 2002).

Even though there have been positive benefits from using $\mathrm{GA}_{3}$ in rabbiteye blueberries, there are problems with small, late-ripening fruit when using this growth regulator (NeSmith and Krewer, 1999; Williamson et al., 1995). The cytokinin compound CPPU has shown some positive results in increasing fruit size and/or set of several crops, including table grapes (Vitis sp.), kiwi fruit (Actinidia chinensis Planch and $A$. deliciosa), apples [Malus domestica (Borkh.) Mansf.], pear (Pyrus communis L.), table olives (Olea eropaea L.), and Japanese persimmon (Diospyros khaki Thunb.) (Antognozzi et al., 1993a, 1993b; Flaishman et al., 2001; Greene, 1989, 1993; Looney, 1993; Nickell, 1985, 1986; Reynolds et al., 1992; Sugiyama and Yamaki, 1995). The objective of this research was to examine possible enhancement of berry size, fruit set, and yield of rabbiteye blueberries using the growth regulator CPPU with and without $\mathrm{GA}_{3}$.

\section{Materials and Methods}

Mature (6 years old in 1999) field-grown 'Tifblue' blueberry plants in Griffin, Ga., were used for this experiment. A split-plot experiment was conducted in Spring 1999 and 2000, with main plots of two levels of $\mathrm{GA}_{3}$ (+ and $\mathrm{GA}_{3}$ ), and subplots of three CPPU treatments (no CPPU, CPPU timing 1, and CPPU timing $2)$. When $50 \%$ or more of flowers were at stage 5 to 6 of development (Spiers, 1978), applica- tions of the growth regulator ProGibb (4\% $\mathrm{GA}_{3}$ ) were made to whole plants. The timing and rate of $\mathrm{GA}_{3}$ were based on previous work (NeSmith and Krewer, 1992, 1997a, 1997b). $\mathrm{GA}_{3}$ treatments consisted of one application of $200 \mathrm{mg} \cdot \mathrm{L}^{-1}$ at the appropriate growth stage, followed by a second application (same concentration) $14 \mathrm{~d}$ later. These were applied to five rows (every other row out of 10 total rows) containing 10 plants in each row. The remaining five rows were not treated with $\mathrm{GA}_{3}$. CPPU applications were applied to single plant plots in each of the $\mathrm{GA}_{3}$ and non-GA $\mathrm{G}_{3}$ rows. The treatments were: 1) no CPPU, 2) CPPU applied $1 \mathrm{~d}$ after the last $\mathrm{GA}_{3}$ application $(\approx 7 \mathrm{~d}$ after flowering), and 3) CPPU applied $10 \mathrm{~d}$ after the last $\mathrm{GA}_{3}$ application $(\approx 17 \mathrm{~d}$ after flowering). All CPPU applications were applied at a concentration of $10 \mathrm{mg} \cdot \mathrm{L}^{-1}$. All growth regulator applications consisted of spraying whole plants to the point of drip using a back pack sprayer. All sprays utilized the nonionic surfactant X-77 at $0.25 \%$. There were five replications (single plant) of each $\mathrm{GA}_{3}$ and CPPU combination. Treated plants were bordered by one plant on each side in the row.

Data collection from all treatments in 1999 consisted of fruit number per plant and average fruit weight. Berry weight was determined two times on a 25-berry sample of ripe fruit from each treatment and each replication. One complete harvest was made for all bushes on 6 July in 1999; however, bird problems prevented continuous harvesting of fruit, so yield estimations were made. Fruit number per plant was determined by harvesting and counting all ripe and green fruit on plants. Yield estimations were made by multiplying fruit number per plant by average berry weight.

In 2000, treatment plants were protected from birds by utilizing commercial bird netting. The netting was put in place just before fruit began to ripen. Data collection during 2000 was the same as in 1999 except for the following additions. In 2000, fruit set of all plants was determined by tagging three shoots per plant and counting the number of flowers per shoot and later counting the number of fruit. Yield was determined for each treatment by hand-harvesting all ripe fruit on four dates in 2000 (29 June, 14 July, 2 Aug., and 17 Aug.). At each harvest, average berry weight was determined on a 100-berry sample of ripe fruit. All data were subjected to analysis of variance procedures (SAS Institute, 1990).

\section{Results and Discussion}

In 1999, berry number per plant was substantially increased for plants treated with CPPU at either timing, while no significant difference was apparent due to $\mathrm{GA}_{3}$ application (Table 1). Likewise, in 2000, fruit set generally increased with applications of both CPPU alone, and CPPU applied in conjunction with $\mathrm{GA}_{3}$ (Table 2). Fruit set overall during 2000 was much greater than in 1999 for all treatments. During 2000, there was a trend (although not significant) for $\mathrm{GA}_{3}$ to increase fruit set compared to pollination alone, which is similar to earlier reports using the growth 
regulator (NeSmith and Krewer, 1992 and 1997b). However, the use of CPPU caused increases in fruit set of both nontreated and $\mathrm{GA}_{3}$-treated plants. CPPU has been shown to increase fruit set in watermelon [Citrullus lanatus (Thunb.) Matsum \& Nak.], muskmelon (Cucumis melo L.), Chinese gourd (Lagenaria leucantha), and Japanese persimmon (Hayata et al., 1995; Hayata et al., 2000; Sugiyama and Yamaki, 1995; Yu et al., 2001). However, in apple, CPPU has been shown to reduce crop load (Greene, 1989), and in grapes CPPU had no effect on berry set (Reynolds et al., 1992; Zabadal and Bukovac, 2000).

Average berry weights at the first harvest during 1999 and 2000 (Table 3) showed a tendency for $\mathrm{GA}_{3}$-treated berries, overall, to be slightly smaller than non-GA $\mathrm{G}_{3}$-treated berries, which agrees with previous reports (NeSmith et al., 1995; NeSmith and Krewer, 1999). In the absence of $\mathrm{GA}_{3}$, average berry weight of CPPU-treated plants was greater than that of plants receiving no CPPU. CPPU applied $17 \mathrm{~d}$ after flowering tended to result in the greatest increase in berry weight as compared to no CPPU. CPPU had much less effect on berry weight when applied in conjunction with $\mathrm{GA}_{3}$. Effects of CPPU and $\mathrm{GA}_{3}$ on berry weight were found across all harvests during 2000 (Table 4). CPPU increased average berry weight by $15 \%$ to $34 \%$ across all harvests when compared to pollination alone.

Research with other crops has shown one of the principle benefits of CPPU is increased fruit size. Grapes have been increased in size by as much as $35 \%$ with CPPU depending on timing and rate (Nickell, 1985, 1986; Reynolds et al., 1992; Zabadal and Bukovac, 2000). In kiwifruit, CPPU applied $14 \mathrm{~d}$ after bloom increased fruit size by more than $25 \%$ (Antognozzi et al., 1993b). Fruit size of apple has been increased by $15 \%$ to $20 \%$ using CPPU, but some resulting misshapened fruit was reported (Curry and Greene, 1993; Greene, 1989, 1993; Sugiyama et al., 1993; Tartarini et al., 1993). Fruit size of other crops, including olive and pear, has been increased with CPPU also (Antognozzi et al., 1983a; Flaishman et al., 2001), while still other crops (watermelon, muskmelon, and Japanese persimmon) have shown no response of fruit size to CPPU (Hayata et al., 1995, 2000; Sugiyama and Yamaki, 1995).

Early work with apples (Greene, 1989) indicated that CPPU thinned crop load, supporting the possibility that the thinning effect was the reason for fruit size increase. However, subsequent research with pear(Flaishman et al., 2001) concluded that there was a direct effect of CPPU on sizing, not just a thinning effect. In the current experiment with blueberries, fruit thinning was not responsible for sizing of CPPU fruit, as many of the treatments with the greater degree of fruit set were those with the larger berry weight. Other investigations have revealed that $\mathrm{CPPU}$ can induce increased cell division and expansion, which leads to increased fruit size (Lewis et al., 1996; Looney, 1993; Yu et al., 2001).

Total yield per plant for 1999 and 2000 indicate no yield differences in response to

Table 1. Total number of berries per bush for the growing season for $\mathrm{GA}_{3}$ - and $\mathrm{CPPU}$ treated 'Tifblue' blueberries in Griffin, Ga., during 1999.

\begin{tabular}{llcr}
\hline \hline & \multicolumn{3}{c}{ Total berry no. per bush for season } \\
\cline { 2 - 4 } CPPU treatment & With GA & Without GA & Avg \\
\hline No CPPU & $435 \mathrm{a} \mathrm{A}^{\mathrm{z}}$ & $553 \mathrm{a} \mathrm{A}$ & $494 \mathrm{a}$ \\
CPPU Timing 1 & $1261 \mathrm{~b} \mathrm{~A}^{2}$ & $988 \mathrm{ab} \mathrm{A}$ & $1124 \mathrm{~b}$ \\
CPPU Timing 2 & $1680 \mathrm{~b} \mathrm{~A}$ & $1422 \mathrm{~b} \mathrm{~A}$ & $1551 \mathrm{~b}$ \\
Average & $1125 \mathrm{~A}$ & $988 \mathrm{~A}$ & \\
\hline
\end{tabular}

${ }^{2}$ Values in a column followed by the same lower case letter were not significantly different at $P \leq 0.05$; values in a row followed by the same capital letter were not significantly different at $P \leq 0.05$.

Table 2. Percent fruit set for $\mathrm{GA}_{3}$ - and CPPU-treated 'Tifblue' blueberries in Griffin, Ga., during 2000 .

\begin{tabular}{llcr}
\hline \hline & \multicolumn{3}{c}{ Fruit set percentage } \\
\cline { 2 - 4 } CPPU treatment & With GA & Without GA & Avg \\
\hline No CPPU & $82 \% \mathrm{a} \mathrm{A}^{2}$ & $68 \%$ a A & $75 \% \mathrm{a}$ \\
CPPU Timing 1 & $85 \%$ ab A & $77 \%$ ab A & $81 \% \mathrm{ab}$ \\
CPPU Timing 2 & $98 \% \mathrm{~b} \mathrm{~A}$ & $93 \% \mathrm{~b} \mathrm{~A}$ & $96 \% \mathrm{~b}$ \\
Average & $88 \% \mathrm{~A}$ & $79 \% \mathrm{~A}$ & \\
\hline
\end{tabular}

${ }^{2}$ Values in a column followed by the same lowercase letter were not significantly different at $P \leq 0.05$; values in a row followed by the same capital letter were not significantly different at $P \leq 0.05$.

Table 3. Average individual ripe berry weight at the first harvest (6 July 1999 and 29 June 2000) for $\mathrm{GA}_{3}$ - and CPPU-treated 'Tifblue' blueberries in Griffin, Ga., during 1999 and 2000.

\begin{tabular}{llcr}
\hline \hline & \multicolumn{3}{c}{ Avg ripe berry wt (g) } \\
\cline { 2 - 4 } CPPU treatment & With GA $_{3}$ & Without GA & Avg \\
\hline & & 1999 & \\
No CPPU & $1.04 \mathrm{a} \mathrm{A}^{z}$ & $1.18 \mathrm{a} \mathrm{B}$ & $1.11 \mathrm{a}$ \\
CPPU Timing 1 & $1.16 \mathrm{a} \mathrm{A}$ & $1.26 \mathrm{ab} \mathrm{A}$ & $1.21 \mathrm{ab}$ \\
CPPU Timing 2 & $1.16 \mathrm{a} \mathrm{A}$ & $1.34 \mathrm{~b} \mathrm{~B}$ & $1.25 \mathrm{~b}$ \\
Average & $1.12 \mathrm{~A}$ & $1.26 \mathrm{~B}$ & \\
& & 2000 & $1.05 \mathrm{a}$ \\
No CPPU & $1.11 \mathrm{a} \mathrm{A}$ & $0.99 \mathrm{a} \mathrm{A}$ & $1.07 \mathrm{a}$ \\
CPPU Timing 1 & $0.98 \mathrm{~b} \mathrm{~A}$ & $1.16 \mathrm{~b} \mathrm{~B}$ & $1.23 \mathrm{~b}$ \\
CPPU Timing 2 & $1.13 \mathrm{a} \mathrm{A}$ & $1.33 \mathrm{c} \mathrm{B}$ & \\
Average & $1.07 \mathrm{~A}$ & $1.16 \mathrm{~A}$ &
\end{tabular}

${ }^{2}$ Values in a column for a year followed by the same lowercase letter were not significantly different at $P \leq 0.05$; values in a row for a year followed by the same capital letter were not significantly different at $P \leq 0.05$.

Table 4. Average individual ripe berry weight over all four harvests for $\mathrm{GA}_{3}$ - and CPPU-treated 'Tifblue' blueberries in Griffin, Ga., during 2000.

\begin{tabular}{llcr}
\hline \hline & \multicolumn{3}{c}{ Avg ripe berry wt (g) } \\
\cline { 2 - 4 } CPPU treatment & With GA & Without GA & Avg \\
\hline No CPPU & $1.02 \mathrm{ab} \mathrm{A}^{z}$ & $0.94 \mathrm{a} \mathrm{A}$ & $0.98 \mathrm{a}$ \\
CPPU Timing 1 & $0.97 \mathrm{a} \mathrm{A}$ & $1.08 \mathrm{~b} \mathrm{~A}$ & $1.03 \mathrm{a}$ \\
CPPU Timing 2 & $1.11 \mathrm{~b} \mathrm{~A}$ & $1.26 \mathrm{c} \mathrm{B}$ & $1.19 \mathrm{~b}$ \\
Average & $1.03 \mathrm{~A}$ & $1.09 \mathrm{~A}$ & \\
\hline${ }^{2}$ Values in a column followed by the same lowercase letter were not significantly \\
different at $P \leq 0.05 ;$ values in a row followed by the same capital letter were not \\
significantly different at $P \leq 0.05$.
\end{tabular}

$\mathrm{GA}_{3}$ overall; however, there was an increase in yield in response to CPPU application (Table 5 ). Yields were more than $200 \%$ greater for CPPU-treated plants in 1999 than for plants receiving no CPPU, although 1999 yields overall were much less than during 2000. In 2000, there were no yield differences between CPPU treatments with $\mathrm{GA}_{3}$; however, in the absence of $\mathrm{GA}_{3}$, CPPU increased yields by as much as $66 \%$. In both years, the yield increases were due to both increased berry numbers per plant and to increased berry size in response to CPPU. Total yield increases have been reported for CPPU used on other crops comparable to the yield increases observed for blueberry (Antognozzi et al., 1993b; Flaishman et al., 2001). Yield increase from $\mathrm{GA}_{3}$ alone did not occur in 1999, although yields for the $\mathrm{GA}_{3}$ alone treatment in 2000 were $36 \%$ greater than for the pollinated control. Yield increases from $\mathrm{GA}_{3}$ under field conditions have been previously reported, and as in the current experiment, results have been variable (NeSmith and Krewer, 1997a; Williamson et al., 1995).

Both growth regulators tended to cause delays in maturity, as is apparent from the percent of the fruit obtained at the first harvest each year (Table 6). Delays in ripening of blueberries from $\mathrm{GA}_{3}$ have been documented previously, and tend to come from the lack of "seed" in fruit rather than from increased fruit loads (NeSmith and Krewer, 1999; Williamson 
Table 5. Total yield per plant for $\mathrm{GA}_{3}$ - and CPPU-treated 'Tifblue' blueberries in Griffin, Ga., during 1999 and 2000.

\begin{tabular}{|c|c|c|c|}
\hline \multirow[b]{2}{*}{ CPPU treatment } & \multicolumn{3}{|c|}{ Total yield (kg/bush) } \\
\hline & With $\mathrm{GA}_{3}$ & Without $\mathrm{GA}_{3}$ & Avg \\
\hline & \multicolumn{3}{|c|}{$1999^{y}$} \\
\hline No CPPU & $0.5 \mathrm{a} \mathrm{A} \mathrm{A}^{\mathrm{z}}$ & 0.7 a A & $0.6 \mathrm{a}$ \\
\hline CPPU Timing 1 & $1.5 \mathrm{~b} \mathrm{~A}$ & $1.3 \mathrm{ab} \mathrm{A}$ & $1.4 \mathrm{ab}$ \\
\hline CPPU Timing 2 & $2.0 \mathrm{~b} \mathrm{~A}$ & $1.9 \mathrm{~b} \mathrm{~A}$ & $1.9 \mathrm{~b}$ \\
\hline \multirow[t]{2}{*}{ Average } & $1.3 \mathrm{~A}$ & $1.3 \mathrm{~A}$ & \\
\hline & \multicolumn{3}{|c|}{2000} \\
\hline No CPPU & 6.8 a A & 5.0 a A & $5.9 \mathrm{a}$ \\
\hline CPPU Timing 1 & 5.5 a A & $7.1 \mathrm{ab} \mathrm{A}$ & $6.3 \mathrm{a}$ \\
\hline CPPU Timing 2 & 6.5 a $\mathrm{A}$ & $8.3 \mathrm{~b} \mathrm{~A}$ & $7.4 \mathrm{a}$ \\
\hline Average & $6.3 \mathrm{~A}$ & $6.8 \mathrm{~A}$ & \\
\hline \multicolumn{4}{|c|}{$\begin{array}{l}\text { }{ }^{2} \text { Values in a column for a year followed by the same lowercase letter were not } \\
\text { significantly different at } P \leq 0.05 \text {; values in a row for a year followed by the same } \\
\text { capital letter were not significantly different at } P \leq 0.05 \text {. } \\
\text { y Yields for } 1999 \text { are estimates made from numbers of berries per plant and average } \\
\text { fruit weight from two sampling dates. Yields for } 2000 \text { are actual harvests from four } \\
\text { dates over the season. }\end{array}$} \\
\hline \multicolumn{4}{|c|}{$\begin{array}{l}\text { Table 6. Percent of total fruit gathered at the first harvest for } \mathrm{GA}_{3} \text { - and CPPU-treated } \\
\text { 'Tifblue' blueberries each year in Griffin, Ga. }\end{array}$} \\
\hline \multirow[b]{2}{*}{ CPPU treatment } & \multicolumn{3}{|c|}{ Percent fruit harvested at first harvest } \\
\hline & With $\mathrm{GA}_{3}$ & Without $\mathrm{GA}_{3}$ & Avg \\
\hline & \multicolumn{3}{|c|}{1999} \\
\hline No CPPU & $37 \%$ a $A^{z}$ & $62 \%$ a $\mathrm{A}$ & $50 \%$ a \\
\hline CPPU Timing 1 & $18 \%$ b A & $37 \%$ b B & $28 \% \mathrm{~b}$ \\
\hline CPPU Timing 2 & $4 \%$ b A & $18 \%$ c A & $11 \% \mathrm{c}$ \\
\hline \multirow[t]{2}{*}{ Average } & $20 \% \mathrm{~A}$ & $39 \% \mathrm{~B}$ & \\
\hline & & 2000 & \\
\hline No CPPU & $15 \%$ a $\mathrm{A}$ & $22 \%$ a A & $19 \%$ a \\
\hline CPPU Timing 1 & $4 \%$ ab A & $13 \%$ ab A & $9 \% \mathrm{ab}$ \\
\hline CPPU Timing 2 & $1 \%$ b A & $4 \%$ b A & $3 \% \mathrm{~b}$ \\
\hline Average & $7 \% \mathrm{~A}$ & $13 \% \mathrm{~A}$ & \\
\hline
\end{tabular}

${ }^{2}$ Values in a column for a year followed by the same lowercase letter were not significantly different at $P \leq 0.05$; values in a row for a year followed by the same capital letter were not significantly different at $P \leq 0.05$.

et al., 1995). In the current experiment, the naturally pollinated treatment ripened the fastest, with $62 \%$ and $22 \%$ of its crop ripe at the first harvest during 1999 and 2000, respectively. The later application of CPPU (timing 2) had the greatest delay in ripening. Less than $5 \%$ of this treatment's fruit were ripe during the first harvest. Others have reported that CPPU tended to delay maturity in apple (Greene, 1989), grape (Reynolds et al., 1992), and Japanese persimmon (Sugiyama et al., 1993).

In summary, this research suggests that CPPU usage can enhance yield of 'Tifblue' rabbiteye blueberries under field conditions, even in the absence of $\mathrm{GA}_{3}$. The yield increase results from both increased fruit set and berry size. The use of $\mathrm{GA}_{3}$ has been beneficial in rabbiteye blueberry production in the Southeast, especially for freeze rescue (NeSmith et al., 1995, 1999). However, fresh fruit varieties often do not benefit from $\mathrm{GA}_{3}$ due to the resulting reduced berry size and delayed ripening. The data here strongly suggest that CPPU may overcome the small berry size problem to a degree, but delays in maturity will likely occur. Berry size and maturity date are less important for processed blueberries; but again, CPPU would likely be useful to increase overall yields of those processed varieties. These findings should encourage further exploration of using CPPU in blueberry production. Experiments to better define rates and timing of the growth regulator are needed, and tests of cultivar and species responses (i.e., rabbiteye vs. southern highbush) need to be conducted as well.

\section{Literature Cited}

Antognozzi, E., P. Proietti, and M. Boco. 1993a. Effect of CPPU (cytokinin) on table olive cultivars. Acta Hort. 329:153-155.

Antognozzi, E., F. Famiani, A. Palliotti, and A. Tombesi. 1993b. Effects of CPPU (cytokinin) on kiwifruit productivity. Acta Hort. 329:150-152.

Curry, E.A. and D.W. Greene. 1993. CPPU influences fruit quality, fruit set, return bloom, and preharvest drop of apples. HortScience 28:115-119.

Flaishman, M.A., A. Shargal, and R.A. Stern. 2001. The synthetic cytokinin CPPU increases fruit size and yield of 'Spadona' and 'Costa' pear (Pyrus communis L.). J. Hort. Sci. Biotechnol. 76:145149.

Greene, D.W. 1989. CPPU influences 'McIntosh' apple crop load and fruit characteristics. HortScience 24:94-96.

Greene, D.W. 1993. A comparison of the effects of several cytokinins on apple fruit set and fruit quality. Acta Hort. 329:144-146.

Hayata, Y., N. Yoshiyuki, and N. Iwasaki. 1995. Synthetic cytokinin-1-(2-chloro-4-pyridyl)-3phenylurea (CPPU) - promotes fruit set and induces parthenocarpy in watermelon. J. Amer. Soc. Hort. Sci. 120:997-1000.

Hayata, Y., Y. Niimi, K. Inoue, and S. Kondo. 2000. CPPU and BA, with and without pollination, affect set, growth, and quality of muskmelon fruit. HortScience 35:868-870.
Lewis, D.H., G.K. Burge, M.E. Hopping, and P.E. Jameson. 1996. Cytokinins and fruit development in the kiwifruit (Actinidia deliciosa). II. Effects of reduced pollination and CPPU application. Physiol. Plant. 98:187-195.

Looney, N.E. 1993. Improving fruit size, appearance, and other aspects of fruit crop "quality" with plant bioregulating chemicals. Acta Hort. 329:120-127.

Lyrene, P.M. and T.E. Crocker. 1983. Poor fruit set on rabbiteye blueberries after mild winters: Possible causes and remedies. Proc. Florida State Hort. Soc. 96:195-197.

Lyrene, P.M. and R.G. Goldy. 1983. Cultivar variation in fruit set and numbers of flowers per cluster for rabbiteye blueberry. HortScience 18:228-229.

Moore, J.N. 1994. The blueberry industry of North America. HortTechnology. 4:96-102.

NeSmith, D.S. and G. Krewer. 1992. Flower bud stage and chill hours influence the activity of $\mathrm{GA}_{3}$ applied to rabbiteye blueberry. HortScience 27:316318.

NeSmith, D.S. and G. Krewer. 1997a. Response of rabbiteye blueberry (Vaccinium ashei) to gibberellic acid rate. Acta Hort. 446:337-342.

NeSmith, D.S. and G. Krewer. 1997b. Fruit set of eight rabbiteye blueberry (Vaccinium ashei Reade) cultivars in response to gibberellic acid application. Fruit Var. J. 51:124-128.

NeSmith, D.S. and G. Krewer. 1999. Effect of bee pollination and $\mathrm{GA}_{3}$ on fruit size and maturity of three rabbiteye blueberry cultivars with similar fruit densities. HortScience 34:1106-1107.

NeSmith, D.S., G. Krewer, and O.M. Lindstrom. 1999. Fruit set of rabbiteye blueberry (Vaccinium ashei) after subfreezing temperatures. J. Amer. Soc. Hort. Sci. 124:337-340.

NeSmith, D.S., G. Krewer, M. Rieger, and B. Mullinix. 1995. Gibberellic acid-induced fruit set of rabbiteye blueberry following freeze and physical injury. HortScience 30:1241-1243.

Nickell, L.G. 1985. New plant growth regulator increases grape size. Proc. Plant Growth Regulat. Soc. Amer. 12:1-7.

Nickell, L.G. 1986. Effects of $N$-(2-chloro-4-pyridyl)$N^{\prime}$-phenylurea on grapes and other crops. Proc. Plant Growth Regulat. Soc. 13:236-241.

Reynolds, A.G., D.A. Wardle, C. Zurowski, and N.E. Looney. 1992. Phenylureas CPPU and thidiazuron affect yield components, fruit composition, and storage potential of four seedless grape selections. J. Amer. Soc. Hort. Sci. 117:85-89.

SAS Institute. 1990. SAS user's guide: Statistics (6th edition). SAS Inst., Cary, N.C.

Scherm, H., D.S. NeSmith, D.L. Horton, and G. Krewer 2002. A survey of horticultural and pest management practices of the Georgia blueberry industry. Small Fruits Rev. (In press.)

Spiers, J.M. 1978. Effect of stage of bud development on cold injury in rabbiteye blueberry. J. Amer. Soc. Hort. Sci. 103:452-455.

Sugiyama, N. and Y.T. Yamaki. 1995. Effects of CPPU on fruit set and fruit growth in Japanese persimmon. Scientia Hort. 60:337-343.

Sugiyama, N., S. Sansavini, D. Neri, and S. Tartarini. 1993. Effect of CPPU on fruit and shoot growth of apple. J. Hort. Sci. 68:673-677.

Tartarini, S., S. Sansavini, and M. Ventura. 1993. CPPU control of fruit morphogenesis in apple. Scientia Hort. 53:273-279.

Williamson, J.G., R.L. Darnell, G. Krewer, J. Vanerwegen, and S. NeSmith. 1995. Gibberellic acid: A management tool for increasing yield of rabbiteye blueberry. J. Small Fruit Viticult. 3:203218.

Yu, J.Q., Y. Li, R.Y. Qian, and Z.J. Zhu. 2001. Changes of endogenous hormone level in pollinated and $\mathrm{N}$ (2-chloropyridyl)- $N^{\prime}$-phenylurea (CPPU)-induced parthenocarpic fruits of Lagenaria leucantha. J. Hort. Sci. Biotechnol. 76:231-234.

Zabadal, T.J. and M.J. Bukovac. 2000. Effect of CPPU on fruit development in seedless and seeded grape cultivars. HortScience 35:496. (Abstr. No. 581.) 